IFN Working Paper No. 734, 2008

\title{
Competition, Takeovers and Gender Discrimination
}

Fredrik Heyman, Helena Svaleryd and Jonas Vlachos 


\title{
Competition, Takeovers and Gender Discrimination*
}

\author{
Fredrik Heyman \\ The Research Institute of Industrial Economics \\ Helena Svaleryd \\ The Research Institute of Industrial Economics, UCLS and UCFS Uppsala University \\ Jonas Vlachos \\ Stockholm University, CEPR and The Research Institute of Industrial Economics
}

Theories of taste-based discrimination predict that competitive pressures will drive discriminatory behavior out of the market. Using detailed matched employer-employee data, we analyze how firm takeovers and product market competition affect firms' gender composition and gender wage gap. Taking into account several endogeneity concerns while using a difference-in-difference framework, we find that the share of female employees increases as a result of an ownership change when product market competition is weak. Furthermore, we find that a takeover reduces the gender wage gap. While the estimated effects are small, the results support the main theoretical predictions.

JEL: J2, J31, J7

Keywords: Discrimination, competition, takeovers, wages

\footnotetext{
* We are grateful for helpful comments from Morten Bennedsen, Sandra Black, Francine Blau, Lennart Hjalmarsson, Lena Nekby and seminar participants at the Research Institute of Industrial Economics, Stockholm University, University of Bergen, the SOLE conference in New York, the ESPE conference in London, the SNEE conference in Mölle and the ETSG conference in Athens. Fredrik Heyman acknowledges financial support from the Swedish Council for Working Life and Social Research (FAS). Helena Svaleryd and Jonas Vlachos acknowledge financial support from Jan Wallander's and Tom Hedelius' Research Foundation and the Swedish Research Council. Address: The Research Institute of Industrial Economics, P.O. Box 55665, SE-102 15 Stockholm, Sweden, fredrik.heyman@ifn.se, helena.svaleryd@ifn.se and jonas.vlachos@ne.su.se
} 


\section{Introduction}

Women earn lower salaries and are far less likely to hold high ranking corporate management positions than men. Even Sweden, a country perceived to enjoy high gender equality, is characterized by large gender differences in wages and carriers (see e.g. Albrecht et al. 2003). Furthermore, women only held 12 percent of top management positions in Swedish publicly listed firms in 2005 (Renstig and Westlin 2006). If these differences occur because of discrimination against women on the labor market, this constitutes a major inefficiency. Ever since 1957, when Becker presented his seminal theory of taste-based discrimination, it has been suggested that labor market discrimination can be competed away, at least if discrimination is based on employer preferences.

An implication of Becker's theory is that competitive pressures will reduce inefficient management practices in general and discriminatory practices in particular. While this is usually interpreted as inefficient firms being competed away from the market, another possibility is that existing firms adjust their behavior when competitive pressures increase the relative cost of poor management. In this process, the firm takeover market can play an important role. First of all, takeovers have long been regarded as a restraint on inefficient management behavior. Second, firms with inefficient management practices may be taken over by other firms. When inefficient management practices allow discriminatory practices to linger in an organization, competitive pressures should improve the relative labor market position for women. This paper will address just this issue; we examine how competitive pressures in the form of takeovers and product market competition affect labor market outcomes for women.

When discrimination pervades the labor market, women are paid less in relation to their

marginal product than men. That being the case, non-discriminatory firms would be expected 
to hire more women than discriminatory firms. On the other hand, a non-discriminatory firm has no incentive to pay women more than the going market wage. The theoretical predictions regarding the effects of competitive pressures on gender wage differences on firm level are hence less straightforward. Still, one can expect that competitive pressures would reduce these differences for two main reasons. First, women often lack career opportunities in discriminatory firms. Since wages are closely tied to an employee's hierarchical position, female relative wages should be higher in non-discriminatory firms. Second, discriminatory owners may disproportionately share firm-level rents with men.

We use detailed Swedish employer-employee data to analyze how product market competition and firm takeovers affect workforce gender composition and gender wage differentials. The study covers the period 1990-2002 and uses data on the entire private sector. In addition to providing high quality data, this study addresses the prediction that firm takeovers affect labor market outcomes for women; previous empirical studies in this area have merely focused on the effects of product market competition. ${ }^{1}$ Moreover, we use a theoretically sound measure of product market competition developed by Boone et al. (2007) and Boone (2008), whereas previous studies have mainly relied on rudimentary measures such as concentration ratios.

\footnotetext{
${ }^{1}$ The only study, at least of which we are aware, studying ownership changes and discrimination, is Hellerstein et al. (2002). They study if firms with a low share of women are more likely to be taken over on a sample of US firms, but find no such effects. They do not, however, study the effects of takeovers on the composition of employees.
} 


\section{Theoretical discussion and earlier literature}

\section{Discrimination due to inefficient management}

Theories of taste-based discrimination suggest that under some conditions, market forces will work to reduce discriminatory or other inefficient management practices. ${ }^{2}$ The reason is that discrimination comes at a cost to the firm owner. Thus, if product market competition is strong, firms that incur the efficiency loss from discriminating against women will be competed away from the market. ${ }^{3}$ Alternatively, firms may change their behavior as competition increases the costs incurred by a discriminating firm. ${ }^{4}$ Despite mixed results from early research on the relation between product market competition and labor market discrimination, later studies tend to find that competition on the product market restrains discrimination (see e.g. Ashenfelter and Hannan 1986, Black and Brainerd 2004, Hellerstein et al. 2002, Meng 2004, and Zweimüller et al. 2008). ${ }^{5}$ Competition on the ownership market is another channel through which discrimination may be reduced. None-discriminatory owners can take over discriminating firms and, by running them more efficiently, earn higher profits. Since the scope for efficiency improvements is likely to be higher in markets with a low degree of product market competition, takeovers and competition can work as substitutes when it comes to reducing discrimination.

\footnotetext{
${ }^{2}$ Hellerstein et al. (2002) provide a simple model that clearly illustrates the main predictions from Becker's theory of discrimination.

${ }^{3}$ Perfect product market competition will put an end to discrimination if there are a sufficient number of potential employers with non-discriminatory tastes. Entry will also terminate discrimination when there is at least one nondiscriminating employer and non-decreasing returns to scale (Becker, 1971).

${ }^{4}$ Weber and Zulehner (2010) study start-ups on Austrian data and find evidence that both mechanisms are at work: the survival rate is significantly shorter for discriminatory firms and surviving discriminatory firms seem to react to the competitive pressures by increasing their female workforce over time.

${ }^{5}$ It should be noted that Zweimüller et al. (2008) analyze gender wage gaps between countries and use a country level indicator of general market orientation.
} 
While outright discrimination may be rare today, there are reasons to expect discriminatory practices to linger in an organization as such. Based on psychological evidence, Bertrand et al. (2005) suggest that a great deal of discrimination may be unintentional, rather than due to preferences for or against a certain group. Hence, well-functioning human resource management may be important for reducing this type of "implicit" discrimination. ${ }^{6}$ To the extent that more efficient firms have better human resource management, the theory of implicit discrimination yields the same predictions for the impact of market forces on the labor market outcome for men and women as the taste-based theory of discrimination. ${ }^{7}$

While the original Becker-theory was derived in an owner-manager setting, it also has implications when ownership and firm management are separated. In such cases, it is possible that market forces help disciplining firm managers who may pursue their own objectives (such as discriminating against women) rather than maximizing shareholder value. ${ }^{8}$ In either setting, we expect there to be a larger share of women employed when product market competition limits inefficient management behavior. Furthermore, we expect firm takeovers to be one channel through which poor management practices are replaced by more efficient ones (Jensen 1988). ${ }^{9}$ Thus, on average, we expect the share of female employees to increase after an acquisition has taken place, and this effect should be especially large when product market competition is weak.

\footnotetext{
${ }^{6}$ In general, improvements in human resource management seem to be related to improvement in productivity (Bloom and Van Reenen, 2010). More specifically, Åslund and Nordström-Skans (2007) find that the introduction of anonymous job applications resulted in a higher rate of female hires in Sweden. This suggests that recruiter biases indeed affect the hiring process, but that better practices reduce discrimination.

${ }^{7}$ Indeed, Bloom and van Reenen (2007) find that poor personnel management is more likely to survive in less competitive industries. Family-controlled firms, in which managers are arguably protected from takeover threats, exhibit particularly poor management practices, for example.

${ }^{8}$ The literature on this topic is too large to cite. However, Nickell (1996) provides a nice discussion of the various mechanisms through which competitive forces can affect corporate performance through this channel and others.

${ }^{9}$ Bertrand and Mullainathan (2003) present evidence that firm managers respond to anti-takeover laws by reducing their efforts to improve firm productivity.
} 
What about effects on the wages of men and women? Since wages are set by the market, it is not clear that takeovers and differences in product market competition should give rise to varying gender wage differentials across firms. Even non-discriminatory profit maximizing owners have no incentive to pay wages higher than the going market wage. To be more precise, gender wage differences ought to be the same for all firms recruiting similar workers in the same labor market. The relevant market for a certain type of labor may, however, only be firms active in one or two industries. In this case, stronger competition on the product market may reduce the industry's equilibrium gender wage gap. If, on the other hand, the type of labor is used in many sectors in the economy, changes in product market competition in one industry should only have negligible effects on the firm's gender wage gap. An analogous reasoning suggests that the effects of a change in firm ownership may be limited since a change in a single firm's attitude towards women will only have marginal effects on equilibrium wages.

This said, there are reasons to study wage differences between men and women. First, female career opportunities may differ between firms as a result of inefficient management practices. ${ }^{10}$ Another reason is that firms may share rents with workers. Weak product market competition should give rise to larger rents and, thus, possibly higher wages. Since discriminating firms prefer men, these rents may be disproportionally shared with their male employees. Indeed, a study of deregulation in the US banking sector by Black and Strahan (2001) find evidence of precisely such gender biased rent sharing; deregulation brought about a reduction of the gender wage gap by reducing male wages more than female. A related study of rent-sharing in Swedish firms also finds that rents are disproportionately shared with male

\footnotetext{
${ }^{10}$ See e.g. Blau and DeVaro (2006) who show that, on average, women have a lower probability of being promoted than men when controlling for productivity. They also show wages to be intimately related to promotions. For a detailed analysis of such glass ceiling effects in Sweden, see Albrecht et al. (2003).
} 
employees (Nekby 2003). Thus, we expect product market competition to reduce male wages, thereby improving the relative wages of women. If a disproportionate share of rents do accrue to men in discriminatory firms, a takeover that reduces discrimination may also reduce the firm's gender wage gap.

\section{Statistical discrimination}

Another reason behind discrimination is information difficulties about workers, so-called statistical discrimination. Hiring practices are then related to group attributes rather than individual characteristics (Phelps 1972; Arrow 1973). ${ }^{11}$ If groups differ in average abilities and information costs are high, even perfectly rational employers would discriminate in the statistical sense as such behavior is profitable. As in the case of implicit discrimination, it is possible that competitive forces compel firms to improve their management, but it is not clear how this would affect hiring practices. Among other things, better management could result in better screening processes of applicants. Improved screening would reduce the reliance on group stereotypes, but the impact of this on hiring depends on the relative change in the signalto-noise ratio, as well as the distribution of attributes in the different groups. Therefore, there are no definite predictions regarding the relation between competition and statistical discrimination.

\footnotetext{
${ }^{11}$ See also Altonji and Blank (1999) for an overview of more recent research along those lines.
} 


\section{Data and descriptive statistics}

\section{Individual and firm-level data}

The analysis is based on several register-based data sets from Statistics Sweden spanning the period 1990-2002 and covering the entire private sector. First, for the period 1996-2002, the financial statistics (FS) contain detailed firm-level information on all Swedish firms in the private sector. For the period 1990-1995, we have data on all manufacturing firms with at least 20 employees and non-manufacturing firms with at least 50 employees. Examples of variables included are value added, capital stock (book value), number of employees, total wages, ownership status, profits, sales and industry affiliation.

Second, Regional Labor Market Statistics (RAMS) includes data on all establishments spanning the period 1990-2002. RAMS adds establishment information on the composition of the labor force with respect to educational level and demographics. ${ }^{12}$

Finally, the individual wage statistics database (LS) contains detailed information from official registers on a very large representative sample of employed individuals. ${ }^{13}$ The LS spans the period 1990-2002 and has approximately 2 million observations per year, which is roughly 50 percent of the Swedish labor force. Examples of variables included are full-time equivalent wages, education, labor market experience and gender. The data sets are matched by unique identification codes. To make the sample of firms consistent throughout the time period, we restrict our analysis to firms with at least 20 employees.

\footnotetext{
12 The plant level data are aggregated at the firm level.

13 The sampling units of Statistics Sweden's annual salary survey consist of firms that are included in Statistics Sweden's firm data base (FS). A representative sample of firms is drawn from FS and stratified according to industry affiliation and firm size (number of employees). The Central Confederation of Private Employers then provides employee information to Statistics Sweden on all its member firms that have (i) at least ten employees and (ii) are included in the sample. Firms with at least 500 employees are examined with probability one. The final sample includes information on around 50 percent of all employees within the entire private sector.
} 
Firm-level data are used to identify takeovers and to construct a measure of the degree of competition. ${ }^{14}$ Ownership changes are identified using two separate procedures. For crossborder ownership changes, data originate from a categorical variable defined as one if at least 50 percent of the equity are foreign owned and zero otherwise. ${ }^{15}$ For domestic takeovers, the official Swedish corporation register, administrated by Statistics Sweden, is used. ${ }^{16}$ This register includes data on all firms in Sweden that are part of a corporation. For each firm in a corporation, we have information on the firms' parent company and the top-mother of the corporation. Our acquisition dummy is equal to one if (i) according to the foreign ownership variable, a firm changes ownership from domestic to foreign or from foreign to domestic, or (ii) a firm becomes part of another corporation, defined as a new top-mother of the corporation, using data from the corporation register. Our data enable us to analyze the effects of both cross-border acquisitions and purely domestic takeovers. Takeovers that we fail to identify are domestic ownership changes of small stand-alone firms that are not part of a corporation.

\footnotetext{
${ }^{14}$ Note that since we only include firms in the private sector we do not study the impact of privatization of state owned firms. This would be a task worthy of a separate investigation.

${ }^{15}$ Statistics Sweden uses the internationally common 50 percent cut-off when defining ownership. We are not able to study whether the results are sensitive to this definition. However, other authors have studied the effects of takeover and in these cases, the results are not sensitive to cut-off values (see e.g. Martins (2004), and Barbosa and Louri (2002)). Although the 50 percent cut-off may be considered as crude, we are ultimately interested in whether a controlling owner is replaced by another controlling owner. Since the actual cut-off at which this occurs depends on the ownership structure as a whole, any cut-off level would be crude.

${ }^{16}$ Although Statistic Sweden is responsible for the corporation register, it has been collected and produced by the consulting firm MM Partners since 1996. This means that we have corporation register information from Statistics Sweden for 1990-1995 and from MM partners for the period 1996-2002. The same methodology for producing the corporation register is, however, used over the entire period. Due to the change in who produces the corporation register in 1996, we choose not to include information on changes in the firms' corporation status between the years 1995 and 1996.
} 


\section{Measure of product market competition}

In the empirical literature on product market competition and discrimination, competition has usually been measured using industry-level concentration ratios and firm-level measures of market power. Product market competition is, however, a rather vague concept that is not easily captured in a single empirical measure. The measurement issue is even more difficult since different changes in market conditions, i.e. anything that can be said to be associated with increased competition (e.g. firm entry or increased substitutability of goods), can have different implications for firm behavior. Therefore, the appropriate measure of product market competition is context specific. In our case, we want to use a measure of competition capturing how severely the market punishes inefficient firm behavior. To this end, we use a sophisticated measure of product market competition developed by Boone et al. (2007).

Based on the theoretical work in Boone (2008), Boone et al. (2007) derive an empirical measure of product market competition precisely along these lines. The starting point is that traditional measures of competition, such as concentration ratios and price-cost margins, are theoretically invalid and especially concentration ratios are of limited empirical value. The theoretically sound measure of competition they derive is based on the within-industry elasticity of profits with respect to marginal costs. The higher the absolute value of this elasticity, the fiercer is competition. In other words, the measure is based on an estimate of how much relative profits are reduced when there is an increase in firms' marginal costs. The measure of competition is generated by estimating the following relation for each 2-digit SNI industry (i.e. 46 to 49 industries, depending on the year of observation), ${ }^{17}$ using OLS:

\footnotetext{
${ }^{17}$ SNI roughly corresponds to Standard Industrial Classification (SIC).
} 


$$
\ln \left(\pi_{j t}\right)=\alpha_{j}+\alpha_{t}+\beta_{t} \ln \left(c_{j t}\right)+\varepsilon_{j t}
$$

Subscript $j$ is a firm-level identifier and $t$ indicates time period. Variable profits, $\pi$, are defined as value added less the total wage bill. Marginal costs are approximated by average variable costs, $c$, which are defined as the total wage bill plus the costs of variable inputs (sales less value added), divided by sales. ${ }^{18}$ Unobservable heterogeneity is taken into account by firm fixed effects, $\alpha_{j}$, and time fixed effects, $\alpha_{t}$. The absolute value of the estimated profit elasticity, $\beta_{t}$, is used as our time-varying industry measure of product market competition.

Using this method, our results show that product market competition (averaged over the 1990-2002 period) is lowest in utilities (SNI 40/41), followed by rental services (71), and the financial sector (65/67) and water transportation (61). Apparel and leather products (18/19) are the most competitive industries, followed by transport equipment (35) and electronic components (32). The resulting ranking of industries thus has a considerable intuitive appeal. The industries characterized by weak competition are mainly active on the domestic market, whereas measured product market competition is high in industries exposed to the international markets. The competition indicators are estimated with considerable precision: averaging by industry over the relevant years shows that the lowest t-statistic for any industry is 2.52 .

The pattern of product market competition across industries is quite stable over time: the rank correlations between competition and its one year and twelve year lags are 0.89 and 0.72, respectively. This is reasonable considering that there are inherent characteristics determining the degree of competition in an industry. The average product market competition

\footnotetext{
${ }^{18}$ In other words, $c=($ sales - value added + wages $) /$ sales.
} 
across industries declined between 1990 and 1999, while it increased thereafter. ${ }^{19}$ This pattern is likely to be related to the severe economic crisis that Sweden experienced during the 1990's when a large number of firms went out of business.

\section{The Swedish takeover market}

As discussed earlier, inefficient management is a potential reason for a takeover. By replacing wasteful management practices, takeovers can increase productivity. Clearly there are also other reasons for takeovers, for example, firms may want to obtain market power or to get access to distribution channels. ${ }^{20}$ The market for firm control in Sweden has become more competitive over time as the rules surrounding foreign ownership have become less complicated. There was a substantial increase in foreign ownership in the Swedish economy during the 1990s. The share of employees in foreign owned firms in the private sector increased from about 9 percent in 1990 to roughly 13 percent in 1996 and 23 percent in 2005 (ITPS, 2006). There are several reasons for this development. For instance, the deregulation of capital and foreign exchange markets in the late 1980s opened up Sweden to inflows of FDI. Two other important factors include Swedish membership in the European Union in 1995 and the currency crisis in 1992. The latter event reduced the cost of Swedish assets and the cost of locating production in Sweden.

On average, 6.5 percent of the firms changed ownership during the period 1991-2002 and there is no trend in takeover activity; the acquisition rate hovers between 5 to 9 percent per year. The highest rate of acquisition is in manufacturing of coke and refined petroleum (16 percent) and the lowest in the tanning and dressing of leather ( 0.1 percent). When it comes to

\footnotetext{
${ }^{19}$ The value is 6.2 for $1990,4.4$ in 1999 and 4.9 in 2002.

${ }^{20}$ However, Devos et al. (2009) show that mergers mainly generate gains by improving resource allocation, rather than increasing market power.
} 
raw numbers, the bulk of takeovers occur in the retail industry. Further, there are no obvious industry specific time trends in merger activity. Table 1 presents the correlation between takeover activity and various industry characteristics at the two digit industry level. There appears to be relatively many takeovers in industries with a low share of females, weak product market competition, low capital intensity, large firms and a large share of high skilled employees. A negative correlation between takeovers and product market competition in a cross-section is no obvious problem in our econometric study since we use firm fixed effects. However, if changes in takeover activity affect product market competition, it could influence the interpretation of our results. As we find no indication of changes in competition being related to the rate of takeover activity, this is unlikely to be a severe problem. $^{21}$

\section{[Table 1]}

\section{Summary statistics}

Variable definitions and descriptive statistics are presented in Table 2. The third column shows the mean and standard deviations for the whole sample of firms and the last column presents individual level data for the matched employer-employee data.

[Table 2]

\footnotetext{
${ }^{21}$ Industry level takeover activity is not correlated with product market competition in subsequent periods. Regression results are available upon request.
} 
As can be seen in the first row, on average about 30 percent of the employees are women and there is substantial variation across firms. ${ }^{22}$ Men and women's full-time equivalent salaries are presented in the lower panel. Pooling all years the raw gender wage gap is 16 percent, which is close to the figure found by Albrecht et al. (2003). In our sample the raw gender wage gap varies a little across years and has decreases somewhat during the period, in 1993 it was 18 percent and 200216 percent. These differences cannot be readily explained by differences in observed characteristics such as education, potential experience and workplace. Using our data we run a regression with log wages on a female dummy, (potential) experience and its square, seven educational dummies, and firm specific fixed effects. Our estimates show an unexplained wage difference of 12 percent.

Note that the reason why the variable means differ in the firm-level and individual-level study is that individual-level data naturally puts more weight on larger firms than data at the firm level. ${ }^{23}$

\section{Testing predictions from the theory of taste-based discrimination}

\section{The share of female employees}

We begin our analysis by examining the effect of product market competition and ownership changes on the share of female employees by estimating the following firm-level regression:

\footnotetext{
${ }^{22}$ The female participation rate in Sweden is higher than 30 percent. In 2002, for example, women made up 48 percent of the total workforce. The lower figures in this data set reflect that women to a high extent are employed in the public sector.

${ }^{23}$ Results for our firm-based analysis also hold for the sample of firms for which we also have access to individual-level data, the point estimates being similar to those for the full sample of firms (the results are available upon request).
} 


$$
\begin{gathered}
y_{j t}=a_{1} \text { acquisition }_{j t}+a_{2} \text { competition }_{j t}+a_{3} \text { acquisition }_{j t} \times \text { competition }_{j}+ \\
X_{j t}{ }^{\prime} a+\mu_{j}+\mu_{t}+\varepsilon_{j t} .
\end{gathered}
$$

Here, $y_{j t}$ is the share of women employed by firm $j$ in time period $t$, while acquisition is an indicator variable taking the value of one in the period where an ownership change is recorded and thereafter. Competition is our time-varying industry-level measure of product market competition, described earlier. An obvious concern with this specification is that acquisitions may have an impact on the level of product market competition. Since our hypothesis is that the efficiency gains from an acquisition will be largest in industries with low levels of competition at the time of the acquisition, we interact the acquisition dummy with a measure of competition from the year of acquisition.

Another concern is that changes in firms' input mix will affect the optimal share of female employees, irrespective of ownership changes. Therefore, we include a vector, $X$, of firm-level control variables such as (log) firm size, capital intensity and the share of employees with higher education. Since all these variables can be endogenous to takeovers, we will present specifications with and without these controls. Finally, $\mu_{j}$ and $\mu_{t}$ are firm and time period fixed effects and $\varepsilon_{j t}$ is the error term. To allow for within firm correlation over time, standard errors are adjusted for clustering at the firm level. In some specifications, when studying the impact of product market competition, we cluster standard errors at the industry level. We expect $a_{1}$ to be positive and $a_{3}$ to be negative. In other words, we expect firms to employ a larger share of women after a new owner has taken control of the firm and that this 
effect is weaker when product market competition is strong. Strong product market competition is, in itself, expected to have a positive effect on the share of women, thus $a_{2}>0 .{ }^{24}$

\section{The endogeneity problem}

In this difference-in-difference setting, all firms that are not changing ownership in the same time period act as the control group. Since firms do not randomly change ownership, this approach suffers from potential endogeneity problems. First of all, theory suggests that firms with inefficient management are more likely takeover targets than non-discriminatory ones. Further, firms that change ownership may already before the takeover be developing differently from firms that are not taken over. ${ }^{25}$ Our first take on the endogeneity problem is to deal with the issue of potentially omitted variables that may be related to the likelihood of being a takeover target. First, this is done by exploiting the fact that all takeovers do not occur in the same time period. Using the "staggered" nature of the data, we compare the baseline estimates from the full sample of firms to the estimates we get when dropping all firms that are never takeover targets from the sample. Since identification in both cases comes from withinfirm variation, the difference between the two approaches lies in the choice of control group. ${ }^{26}$ If takeover targets as a group have different observable and unobservable characteristics than other firms, using the target sample gives a better estimate of the actual takeover effect, provided that the characteristics are not time varying. Next, we make use of very flexible

\footnotetext{
${ }^{24}$ Our measure of competition is an estimated regressor which should be considered when estimating the standard errors. However, Murphy and Topel (1985) derive a correction for two-stage models of this kind and Hardin (2002) shows that the Huber-White sandwich estimator is asymptotically identical to the Murphy-Topel estimator. To allow for within firm or industry correlation over time, standard errors in our paper are adjusted for clustering at the firm or industry level. This adjustment is a cluster-robust version of the Huber-White sandwich estimator.

${ }^{25}$ In other words, the concern is that the "parallel trends" assumption is violated or, more technically, that acquisitions are correlated with the error term.

${ }^{26}$ See Stevenson and Wolfers (2006) for a detailed discussion of such a "staggered" difference-in-difference approach.
} 
empirical specifications allowing takeover targets to be on a different trend than other firms and allowing the effects of observable firm characteristics to interact with the time period fixed effects. Finally, we undertake a before-and-after analysis checking if the timing of events is consistent with takeovers being the driving force. ${ }^{27}$

\section{Wages}

We study how product market competition and takeovers affect the gender wage difference by estimating the following individual-level regression:

$$
\begin{aligned}
& \ln \left(\text { wage }_{i j t}=b_{1} \text { acquisition }_{j t} \times \text { wom }_{i}+b_{2} \text { competition }_{j t} \times \text { wom }_{i}+b_{3} \text { acquisition }_{j t}\right. \\
& +b_{4} \text { competition }_{j t}+X_{j t}{ }^{\prime} b+Z_{i t}{ }^{\prime} b+\mu_{i j}+\mu_{t}+\varepsilon_{i j t} .
\end{aligned}
$$

In this regression, $\ln (\text { wage })_{i j t}$ is the $\log$ of the full-time equivalent monthly wage of an individual $i$, employed by firm $j$ at time period $t$, and wom is a dummy variable taking the value of one for women. The interaction terms should be self-explanatory. $X$ is a vector of timevarying firm-level controls and $Z$ is a vector of time-varying individual controls. We include a "spell" fixed-effect $\mu_{i j}$ for each unique firm-individual combination (see e.g. Andrews et al. 2005). ${ }^{28}$ This variable will pick up the effect of all time invariant individual characteristics, including the main effect of being female. Finally, $\mu_{t}$ are time fixed effects and $\varepsilon_{i j t}$ is the error term. As the effect of control variables may differ between men and women we interact all control variables and the time fixed effect with wom.

\footnotetext{
${ }^{27}$ This set of robustness checks is similar to that undertaken by Bertrand and Mullainathan (1999).

${ }^{28}$ Note that in the case of no mobility between firms, individual fixed-effects and individual-firm spell fixedeffects are identical. Since the structure of our data is such that information on employees originates from repeated samples of firms, there is limited mobility between firms over time. This means that individual fixed effects and spell-fixed effects are very similar.
} 
We expect both $b_{1}$ and $b_{2}$ to be positive. In case of pre-takeover discrimination, a takeover should reduce the gender wage differences. Similarly, intense product market competition should reduce the scope for discrimination and wage differences should be relatively small when competition is high.

One possible channel between competition and gender wage differences is through rent-sharing. This mechanism will be directly addressed by interacting measures of profitability with our measures of competitive pressures.

\section{Results}

Our main hypotheses concerning the impact of competitive pressures on female labor market outcomes rely on the assumption that entering owners of a firm will run the firm in a more efficient way than previous owners. There is a substantive literature on the productivity effects of takeovers (see e.g. Conyon et al. (2002), and Balsvik and Haller (2010) and the references therein) and we cannot fully address this question here. Before moving to the main results, however, we start by presenting some indicative evidence of such a mechanism in our sample of firms.

In Table 3, we run value added per worker - a commonly used proxy for labor productivity - on our takeover indicator, using a firm fixed effects model. The estimated coefficient is positive and statistically significant thus indicating that labor productivity increases after a takeover. In column two, we see that this productivity enhancing effect of a takeover is particularly large when product market competition is weak. Both these results are consistent with the hypothesized mechanism. In columns three and four, we add two potentially endogenous control variables that can affect labor productivity; share of highly 
educated workers and capital per labor ratio. Once more, the results indicate that labor productivity is increasing following a takeover and that the association is particularly strong in less competitive industries.

[Table 3 here]

\section{Evidence of taste-based discrimination in employment decisions}

The question we now address is whether employment decisions are related to takeovers and the degree of product market competition. If this is the case, we expect takeovers to increase the share of women employed, in particular when product market competition is weak. An increase in product market competition should also in itself induce the firm to hire more women. Table 4 presents results showing some evidence in line with these predictions.

[Table 4]

In the first column, we estimate the effect of a takeover using a within firm differencesin-differences specification. As can be seen, there is weak evidence of stronger product market competition being associated with a higher share of female employees. The takeover effect is small and not statistically significant, however. In the second column, we consider the interaction effect between takeovers and competition. In line with our expectations, we see that a takeover has a larger effect if product market competition is weak. Both the estimates of the direct effect and the interaction effect have the predicted signs and are statistically significant 
at the 1 percent level. Including a set of (potentially endogenous) firm level control variables (results presented in column three) does not affect the results. In column four, we only include domestic ownership changes and in column five, we only include cross-border acquisitions. There is some difference in the estimated coefficient size but qualitatively, the results point in the same direction.

In column six we include the share of women at the two-digit industry level. According to our hypotheses this is an endogenous variable since the level of product market competition should affect the share of women employed in the industry. As expected the effect of product market competition is therefore somewhat weaken. The estimated effect of a takeover remains unchanged however.

The estimated magnitudes of the interaction term and the direct acquisition effect are a cause for some concern. At higher than median levels of product market competition, it appears as if a takeover reduces the share of female employees - a finding that is hard to reconcile with any theory of discrimination. To more closely investigate these effects, we study the effect of a takeover in sectors with low, medium and high product market competition. The results presented in column seven show that a takeover has a positive effect on the share of women when the product market competition is weak. Quantitatively speaking, the effect of a takeover is small: When the product market competition is weak a takeover increases the share of women employed with 0.4 percentage point. For a firm with an average share of women it implies an increase with 1.3 percent. In sectors with a medium level of competition there is no effect of a takeover and in highly competitive sectors there is a weak negative effect of a takeover on the share of women employed. While the negative effect in highly competitive 
industries is at odds with the theoretical predictions, it should be noted that the coefficient is small and only marginally statistically significant.

\section{Robustness checks}

Although the basic results show that a takeover affects the employment decision in the firm, several concerns remain. The most obvious objection to the results presented in Table 4 might be that takeover targets differ from those of other firms in many respects. In this section, we will address these concerns in different ways.

\section{Are takeover targets different?}

The difference-in-difference estimates will be corrupt if the share of women employed in the firms that change ownership follow a different trend than other firms. Our first take on this problem is to allow different time trends for the two groups of firms. In the first two columns of Table 5, we see that our results are not affected by allowing separate trends. Another way to make sure results are not due to differences between firms which change and firms which do not change ownership is to restrict the analysis to firms which change ownership. In columns three and four in Table 5, we only include firms that changed ownership at some point in time, thereby changing the control group to firms that will, but have not yet changed ownership. The effects are thus estimated only using the staggered nature of takeovers.

A further concern is that firms changing ownership are differently affected by shocks contemporaneous to the takeover. Such shocks may cause the firms to adjust the input factors

which, in turn, may cause firms to adjust the optimal share of female employees. One way to account for this is to allow the coefficient of the other explanatory variables to change over 
time by interacting all observable firm characteristics with the time period fixed effects. The results are presented in columns five and six. In these specifications, we also include a separate time trend for firms that change ownership over the period.

The results largely remain the same between all different specifications and very close to the original estimates. All in all, the results suggest that the effects we are estimating are due to the takeover and not to some unobserved trends affecting firms in the takeover sample or differences in reactions to contemporary shocks. ${ }^{29}$

[Table 5]

\section{Takeover dynamics}

Another potential concern is that a short-term change in economic conditions induces both an ownership change and an increase in the share of female employees. In this case, we expect to see some effect of the takeover prior to the actual change in ownership. In Table 6, we analyze the dynamics of the effect of a takeover by investigating how the takeover effect is spread over time.

In the first column, we investigate the effect of the takeover after one, two and three years or more. To this end, we include a dummy for the year of the takeover, Acquisition $t=0$, and three dummies capturing the periods after the change of ownership. Acquisition $t+1$ is a dummy for the period after the takeover, Acquisition $t+2$ for two periods after the takeover and Acquisition $>t+2$ refers to a dummy that takes the value of one, three periods or more after the takeover. The results show an instant effect of the takeover that then remains constant over

\footnotetext{
${ }^{29}$ Since the effects are consistent between specifications using different functional forms, we will from now on focus our attention on the more easily interpreted specifications using linear interaction terms.
} 
time. In the second column, we study whether the share of women started to increase prior to the actual takeover. This is done by including a dummy for the year before the takeover, Acquisition $t-1$, and a dummy for the year two years prior to the takeover, Acquisition $t$-2. Inspecting the estimates reported in the second column, we see no effect of either of the dummies, thus suggesting that there was no effect prior to the takeover. In the third column, we allow for effects both before and after the takeover. Consistent with previous results, there is no effect before the takeover and the impact of the takeover increases somewhat over time. ${ }^{30}$ In the last three columns of Table 6, we perform the same exercise as above but only using the sample of firms that changes ownership at some point in time. The results are essentially identical between the two different samples.

[Table 6]

\section{Alternative explanations}

An alternative explanation to the results is that firms that change ownership also increase their number of employees. As the number of potential female employees is likely to be relatively large among younger cohorts, the share of women employed by the firm could therefore increase mechanically after a takeover. To explore this hypothesis, we regress (the log of) firm size on the acquisition takeover dummy, the measure of product market competition and an interaction term. In the first column of Table 7, we find a marginally significant effect of takeovers on firm size. In columns two and three, we analyze how the share of women among the relatively young (up to 39 years) and old (above 40 years) employees are affected by a

\footnotetext{
${ }^{30} \mathrm{We}$ have also run similar regressions including the lagged and lead values of the interaction between acquisition and product market competition. The interaction effect is negative for all time periods after the takeover and insignificant for all time periods before. Results are available upon request.
} 
takeover. As the share of women in both age groups increases after the takeover, we are quite assured that our main results are not driven by mechanical composition changes.

\section{[Table 7]}

Another potential mechanical explanation for our results is that firms that are taken over also tend to outsource various parts of the production process. To the extent that women are overor underrepresented in the lines of production being outsourced this can, again mechanically, affect the share of female employees in a firm. Unfortunately, we do not have any data on outsourcing but, for a subset of firms, we have firm-level data on offshoring measured as the share of imported intermediate goods in total sales. In column 4, we run our main regression on the sample of firms for which we have offshoring data. In column 5, we add the offshoring measure and in column 6 also an interaction with Competition and find that the results remain unchanged.

Finally, in the last column of Table 7, we run the main regression but exclude firms that experience a particular (more than 80 percent) increase in the number of employees in the year following the ownership change. Once more, the results remain unchanged, indicating that we are not just capturing some mechanical effect that coincides with the takeover.

\section{Sub-group analysis}

The results concerning the impact of takeovers on the share of female employees appear to be robust to various specifications. It is, however, possible that there are important heterogeneities among different employee subgroups. To analyze this, we calculate the share of women among 
employees with low, medium, and high levels of education. For a more limited sample of firms, we also have employee classifications and can calculate the share of female managers and CEOs.

As can be seen in the first three columns of Table 8, the increase in the share of female employees appears to be concentrated among those with medium levels of education. In the last two columns, we find no significant effect of takeovers on the share of female managers or CEOs. As glass ceiling effects (Albrecht et al. 2003) should be more concentrated among the most well educated and among the highest ranking employees, this can be seen as evidence against takeovers affecting the career opportunities of women.

\section{[Table 8]}

\section{Wages}

So far, we have found support for the notion that market forces improve the relative labor market outcomes for women. Now, we turn to studying individual wages. The question we ask is whether female relative wages are affected by a takeover or by the degree of product market competition. In this part of the analysis, we control for employee-firm spell fixed effects to isolate the effect of a change in ownership on an individual's wages. We also control for timevarying firm characteristics such as number of employees, capital intensity and the fraction of the workforce that is high skilled. We also include the square of (potential) work life experience. $^{31}$ Since impact of the different covariates may differ for men and women we

\footnotetext{
${ }^{31} \mathrm{We}$ do not have actual work experience. Instead we use a measure of potential experience: age minus years of schooling minus seven. As we are using spell-fixed effects, the effect of experience (not squared) is captured by the time-fixed effects.
} 
interact all control variables and the time effects with the gender dummy. This will control for factors such as that women on average have lower actual work experience than men, which in turn affect wages (see e.g. Blau and Kahn, 1997).

The results are reported in Table 9. Inspecting the first column, we see a positive effect of a takeover on female relative wages. The magnitude of the effect is small: A takeover is associated with a 0.8 percent increase in women's relative wages. Since the wage gap between men and women in our sample is 12 percent after adjusting for educational attainment, experience and firm fixed effects, a takeover reduces the gender wage gap by about 7.5 percent. We also see in column 1 that increased product market competition appears to reduce wages, but there is no significant difference in the relationship between competition and the gender wage gap.

Next, we study whether the effect of takeovers differ depending on the level of product market competition. In contrast to the results found on the effect on the share of women, the impact of takeovers is not related to the degree of product market competition.

[Table 9]

One channel through which competition may reduce the gender wag gap is rentsharing. In column 3, we look at this directly by including profits per employee and interacting this with a female dummy and the takeover indicator. Our hypothesis is that an ownership change will increase the rent-sharing with female employees relative to the rent-sharing with male employees. In line with this hypothesis, we find the triple interaction-term between these variables to be positive and marginally statistically significant. In column 4, we find no 
indication that the gender bias of rent-sharing is systematically related to product market competition. In columns 5 and 6 , we include interactions between both acquisitions and product market competition and find rent-sharing to be systematically more in favor of women following a takeover. In column 5 the standard errors are clustered at the firm-level and in column 6 at the industry level.

\section{Conclusions}

Theories of taste-based discrimination predict that discriminatory practices due to employer preferences should not prevail in competitive markets and competitive forces should reduce gender differences in labor market outcomes. The findings in this paper indicate that takeovers and product market competition do indeed have a positive impact on the relative position of Swedish female employees. According to theory, discriminatory employers will hire fewer women reducing the demand for female labor depressing women's wages. A nondiscriminatory owner will then choose to hire more women to the going market wage. Thus, when a non-discriminatory owner takes over a discriminating firm we expect the share of women employed to increase. In contrast, the effect on within firm gender wage differentials is not clear. A reason why relative wages could be affected by a discriminatory firm is that wages may reflect differences in female career opportunities.

We use detailed Swedish employer-employee data on the private sector to analyze how product market competition and firm takeovers affect workforce gender composition and gender wage differentials. In line with these predictions we find that when product market 
competition is weak, ${ }^{32}$ a takeover leads to a 1.3 percent increase in the share of female employees for a firm with an average rate of female employment. The effect is concentrated among women with medium level of education whereas we find no effects on the share of managers and CEOs. For firms active on markets with medium or strong product market competition, takeovers have no effect on the gender composition of the firm's workforce. Moreover, we find that a takeover reduces the within firm gender wage gap with 7.5 percent. A takeover also reduces the gender differences in rent-sharing, thus suggesting that discriminatory practices may work through this channel. While these effects are small they suggest that takeovers reduce discriminatory management practices. A reason why the effects found here are small in magnitude could be that the mere threat of takeovers provides incentives to manage firms efficiently. An interesting venue for future research would thus be to analyze how the competitiveness of the market for corporate control affects discriminatory behavior.

We find that increased industry level product market competition leads to a small increase in the share of women employed in firms in these industries. This does however not translate into reductions in the industry level wage gap. One explanation for this result could be that the labor force is not sector specific and thus increased demand for women in one sector increase wages for all women. Product market competition in one industry would then have only negligible effects on the firm's gender wage gap.

Our results do not refute the possibility of other types of discrimination. Statistical discrimination, for example, may affect the position of women on the labor market. However, also statistical discrimination could be affected by takeovers and product market competition since competitive pressures may improve the quality of the hiring and promotion processes.

\footnotetext{
${ }^{32}$ For firms active in industries with a level of product market competition at the 33 percentile or lower.
} 


\section{References}

Albrecht, James, Anders Björklund, and Susan Vroman 2003. "Is There a Glass Ceiling in Sweden?" Journal of Labor Economics, Vol. 21, No. 1, pp. 145-77.

Altonji, Joseph G., and Rebecca M. Blank 1999. "Race and Gender in the Labor Market.” In

Orley C. Ashenfelter and David Card, eds., Handbook of Labor Economics, pp. 3144 259. Amsterdam, The Netherlands: Elsevier Science B.V., 1999.

Andrews, Martyn J., Thorsten Schank, and Richard Upward 2005. "Practical Estimation Methods for Linked Employer-Employee Data." IAB Discussion Paper 29/2005, Nurnberg.

Arrow, Kenneth J. 1973. "The Theory of Discrimination.” In Orley C. Ashenfelter and Albert Rees, eds., Discrimination in Labor Markets. Princeton, NJ: Princeton University Press. Ashenfelter, Orley, and Timothy Hannan 1986. "Sex Discrimination and Product Market Competition: The Case of the Banking Industry." Quarterly Journal of Economics, Vol. 101, No. 1, pp. 149-74.

Åslund, Olof, and Oskar Nordström-Skans 2007. "Do Anonymous Job Application Procedures Level the Playing Field?” IFAU Working Paper 2007:31.

Balsvik, Ragnhild, and Stefanie A. Haller 2010. "Picking 'Lemons' or Picking 'Cherries'? Domestic and Foreign Acquisitions in Norwegian Manufacturing." Scandinavian Journal of Economics, Vol. 112, No. 2, pp. 361-87.

Barbosa, Natalia, and Helen Louri 2002. "On the Determinants of Foreign Multinational Ownership Preferences: Evidence from Greece and Portugal.” International Journal of Industrial Organization, Vol. 20, No. 4, pp. 493-515. 
Becker, Gary S. 1957, 1971. The Economics of Discrimination. Chicago: Chicago University Press.

Bertrand, Marianne, and Sendhil Mullainathan 1999. "Is There Discretion in Wage Setting? A Test Using Takeover Legislation.” Rand Journal of Economics, Vol. 30, No. 3, pp. $535-54$.

Bertrand, Marianne, and Sendhil Mullainathan 2003. "Enjoying the Quiet Life? Corporate Governance and Managerial Preferences.” Journal of Political Economy, Vol. 111, No. 5, pp. 1043-75.

Bertrand, Marianne, Dolly Chugh, and Sendhil Mullainathan 2005. "Implicit Discrimination." American Economic Review, Vol. 95, No. 2, pp. 94-8.

Black, Sandra E., and Elizabeth Brainerd 2004. "Importing Equality? The Impact of Globalization on Gender Discrimination.” Industrial and Labor Relations Review, Vol. 57, No. 4, pp. 540-59.

Black, Sandra E., and Philip E. Strahan 2001. "The Division of Spoils: Rent-Sharing and Discrimination in a Regulated Industry." American Economic Review, Vol. 91, No. 4, pp. 814-31.

Blau, Francine and John DeVaro, 2007. "New Evidence on Gender Differences in Promotion Rates: An Empirical Analysis of a Sample of New Hires”, Industrial Relations, Vol 46, No 3, pp. 511-550.

Blau, Francine and Lawrence Kahn, 1997. "Swimming Upstream: Trends in the Gender Wage Differential in the 1980s", Journal of Labor Economics, Vol. 15, No. 1, pp. 1-42. 
Bloom, Nick, and John Van Reenen 2007. "Measuring and Explaining Management Practices Across Firms and Countries." Quarterly Journal of Economics, Vol. 122, No. 4, pp. $1351-408$.

Bloom, Nick, and John Van Reenen 2010. "Human Resource Management and Productivity." forthcoming in Handbook of Labor Economics.

Boone, Jan 2008. “A New Way to measure Competition.” Economic Journal, Vol. 118, No. 531, pp. $1245-61$.

Boone, Jan, Jan C van Ours, and Henry van der Wiel 2007. "How (Not) to Measure Competition.” CEPR Discussion paper No. 6275.

Conyon, Martin, Sourafel Girma, Steve Thompson, and Peter Wright 2002. "The Productivity and Wage Effects of Foreign Acquisition in the United Kingdom.” Journal of Industrial Economics, Vol. 50, No. 1, pp. 85-102.

Devos, Erik, Palani-Rajan Kadapakkam, and Srinivasan Krishnamurthy 2009. "How Do Mergers Create Value? A Comparsion of Taxes, Market Power, and Efficiency Improvements as Explanations for Synergies." Review of Financial Studies, Vol. 22, No. 3, pp. 1179-211.

Hardin, James W. 2002. “The Robust Variance Estimator for Two-Stage Models.” The Stata Journal, Vol. 2, No. 3, pp. 253-66.

Hellerstein, Judith, David Neumark, and Kenneth R. Troske 2002. "Market Forces and Sex Discrimination." Journal of Human Resources, Vol. 37, No. 2, pp. 353-80.

ITPS (Institute for Growth Policy Studies) 2006. Utlandsägda företag 2005. Östersund, Sweden: ITPS. 
Jensen, Michael 1988. "Takeovers: Their Causes and Consequences." Journal of Economic Perspectives, Vol. 2, No. 1, pp. 21-48.

Martins, Pedro 2004. "Do Foreign Firms Really Pay Higher Wages? Evidence From Different Estimators.” IZA Discussion Paper nr 1388.

Meng, Xin 2004. "Gender Earnings Gap: The Role of Firm Specific Effects." Labour Economics, Vol. 11, No. 5, pp. 555-73.

Murphy, Kevin. M., and Robert H. Topel 1985. "Estimation and Inference in Two-Step Econometric Models." Journal of Business and Economic Statistics, Vol. 3, No. 4, pp. $370-9$.

Nekby, Lena 2003. "Gender Differences in Rent Sharing and its Implications for the Gender Wage Gap, Evidence from Sweden.” Economics Letters, Vol. 81, No. 3, pp. 403-10.

Nickell, Stephen 1996. "Competition and Corporate Performance." Journal of Political Economy, Vol. 104, No. 4, pp. 724-46.

Phelps, Edmund S. 1972. "The Statistical Theory of Racism and Sexism." American Economic Review, Vol. 62, No. 4, pp. 659-61.

Renstig, Monica, and Karin Westli 2006. Kvinnliga chefer i näringslivet 2006. Stockholm: Women's Business Research Institute.

Stevenson, Betsey, and Justin Wolfers 2006. "Bargaining in the Shadow of the Law: Divorce Laws and Family Distress." Quarterly Journal of Economics, Vol. 121, No. 1, pp. 26788.

Weber, Andrea, and Christine Zulehner 2010. "Competition and Gender Prejudice: Are Discriminatory Employers Doomed to Fail?" American Economic Review Papers and Proceedings, Vol. 100, No. 2, pp. 358-61. 
Zweimüller, Martina, Rudulf Winter-Ebner, and Daniel Weichselbaumer 2008. "Market Orientation and Gender Wage Gaps: an International Study.” Kyklos, Vol. 61, No. 4, pp. 615-35. 
Table 1. Correlations between acquisition and industry level variables

\begin{tabular}{|l|c|c|c|c|c|c|}
\hline & $\begin{array}{c}\text { Share } \\
\text { women }\end{array}$ & Competition & Capital/L & Size & Value added/L & $\begin{array}{c}\text { Share high } \\
\text { skilled }\end{array}$ \\
\hline Acquisition & -0.128 & -0.115 & -0.087 & 0.155 & 0.029 & 0.090 \\
& $(0.001)$ & $(0.004)$ & $(0.030)$ & $(0.000)$ & $(0.469)$ & $(0.025)$ \\
\hline
\end{tabular}

Presented are correlation coefficients between industry means at the 2-digit SIC (SNI2) level. P-values within brackets. 
Table 2. Variable definitions and descriptive statistics.

\begin{tabular}{|c|c|c|c|}
\hline Firm variables & & $\begin{array}{l}\text { Sample: } \\
\text { Firm- } \\
\text { level } \\
\text { study }\end{array}$ & $\begin{array}{l}\text { Sample: } \\
\text { individual- } \\
\text { level study }\end{array}$ \\
\hline Share women & Number of women/employees & $\begin{array}{c}0.317 \\
(0.247)\end{array}$ & -- \\
\hline Acquisition & $\begin{array}{l}\text { A dummy variable that takes the value of one in the } \\
\text { year, and all periods after, the firm changes } \\
\text { ownership from foreign to domestic or domestic to } \\
\text { foreign. }\end{array}$ & $\begin{array}{c}0.247 \\
(0.431)\end{array}$ & $\begin{array}{c}0.404 \\
(0.491)\end{array}$ \\
\hline Competition & $\begin{array}{l}\text { The elasticity of variable profits to average variable } \\
\text { costs. Divided by } 100 \text {. See text for full definition. }\end{array}$ & $\begin{array}{c}0.048 \\
(0.019)\end{array}$ & $\begin{array}{c}0.053 \\
(0.021)\end{array}$ \\
\hline Size & Number of employees. & $\begin{array}{c}125 \\
(612)\end{array}$ & $\begin{array}{c}4592 \\
(8327)\end{array}$ \\
\hline Capital/L & $\begin{array}{l}\text { (Net property, plant and equipment)/employees (in } \\
\text { million SEK). }\end{array}$ & $\begin{array}{c}0.290 \\
(1.038)\end{array}$ & $\begin{array}{c}0.412 \\
(1.084)\end{array}$ \\
\hline Share high skilled & $\begin{array}{l}\text { Number of high skilled workers with at least } 3 \text { years } \\
\text { of post- secondary education) / employees. }\end{array}$ & $\begin{array}{c}0.193 \\
(0.212)\end{array}$ & $\begin{array}{c}0.215 \\
(0.181)\end{array}$ \\
\hline Value added/L & $\begin{array}{l}\text { (Sales-operational expenses excluding wages) / } \\
\text { employees (in million SEK). }\end{array}$ & $\begin{array}{c}0.429 \\
(0.369)\end{array}$ & $\begin{array}{c}0.487 \\
(0.434)\end{array}$ \\
\hline Profits per employee & Profits, net of financial deduction/employees & $\begin{array}{l}0.051 \\
(0.515) \\
(0.515)\end{array}$ & $\begin{array}{c}0.100 \\
(0.550)\end{array}$ \\
\hline Offshoring & $\begin{array}{l}\text { Share of imported intermediate goods in total sales. } \\
\text { Only available for the period } 1997-2002 \text {. }\end{array}$ & $\begin{array}{c}0.057 \\
(0.126)\end{array}$ & -- \\
\hline $\begin{array}{l}\text { Number of firm-year } \\
\text { observations }\end{array}$ & & 128,848 & -- \\
\hline Individual variables & & & \\
\hline $\ln ($ Wage $)$ women & $\begin{array}{l}\text { Monthly full-time equivalent salary, including wage, } \\
\text { bonus, payment for overtime and work at unsocial } \\
\text { hours. }\end{array}$ & -- & $\begin{array}{c}9.688 \\
(0.264)\end{array}$ \\
\hline $\ln ($ Wage $)$ men & & & $\begin{array}{c}9.840 \\
(0.324)\end{array}$ \\
\hline Experience & $\begin{array}{l}\text { Age minus number of years of schooling minus } \\
\text { seven. }\end{array}$ & -- & $\begin{array}{c}22 \\
(13)\end{array}$ \\
\hline Women & Dummy = 1 if female. & -- & $\begin{array}{c}0.343 \\
(0.475)\end{array}$ \\
\hline $\begin{array}{l}\text { Number of individual- } \\
\text { year observations }\end{array}$ & & -- & $9,989,596$ \\
\hline
\end{tabular}

Presented are means with standard deviations within brackets. The data cover Swedish firms and individuals for the period 1990-2002. The panel of firms is unbalanced and the median number of observations per firm is 4 . All monetary variables are in 1995 SEK. 
Table 3. The effect of acquisitions on labor productivity. Firm-level estimates 1990-2002.

\begin{tabular}{l|cccc}
\hline & $(1)$ & $(2)$ & $(3)$ & $(4)$ \\
\hline \multirow{3}{*}{ Acquisition } & & & & \\
& $0.015^{* * *}$ & $0.055^{* * *}$ & $0.014^{* * *}$ & $0.044^{* * *}$ \\
Competition & $(0.005)$ & $(0.016)$ & $(0.005)$ & $(0.013)$ \\
& & -0.011 & & -0.126 \\
Acq.xcompetition & & $(0.120)$ & & $(0.113)$ \\
& & $-0.863^{* * *}$ & & $-0.629 * * *$ \\
Capital/L & $(0.265)$ & & $(0.225)$ \\
& & & $0.097 * * *$ & $0.096^{* * *}$ \\
Share high skilled & & & $(0.013)$ & $(0.013)$ \\
& & -0.054 & -0.056 \\
Firm FE & & $(0.047)$ & $(0.046)$ \\
Year FE & & & yes \\
Observations & yes & yes & yes & yes \\
Number of firms & 128,848 & yes & 128,848 & 128,848 \\
\hline R-squared & 27,104 & 128,848 & 27,104 & 27,104 \\
\hline
\end{tabular}

The dependent variable is the value-added per employed. Acquisition takes the value of one in the acquisition period and thereafter; zero before. Competition is the industry level of product market competition. Capital/L is the capital-labor ratio. Share high skilled is the share of employees with post-secondary education. All regressions include firm-level fixed effects and year fixed effects. Standard errors are adjusted for clustering at the firm level. $* * *, * *, *$ show significance at the 1,5 and 10 percent level, respectively 
Table 4. The effect of takeovers and product market competition on the share of women employed. Firm-level estimates 1990-2002.

\begin{tabular}{|c|c|c|c|c|c|c|c|}
\hline & (1) & (2) & (3) & (4) & $(5)$ & $(6)$ & $(7)$ \\
\hline & & & & Domestic & $\begin{array}{l}\text { Cross- } \\
\text { border }\end{array}$ & & \\
\hline Acquisition & $\begin{array}{c}0.001 \\
(0.001)\end{array}$ & $\begin{array}{c}0.010 * * * \\
(0.002)\end{array}$ & $\begin{array}{c}0.010 * * * \\
(0.002)\end{array}$ & $\begin{array}{c}0.007 * * \\
(0.003)\end{array}$ & $\begin{array}{c}0.016^{* * * *} \\
(0.005)\end{array}$ & $\begin{array}{c}0.009 * * * \\
(0.002)\end{array}$ & \\
\hline Competition & $\begin{array}{l}0.044 * \\
(0.027)\end{array}$ & $\begin{array}{c}0.077 * * * \\
(0.028)\end{array}$ & $\begin{array}{c}0.075 * * * \\
(0.028)\end{array}$ & $\begin{array}{c}0.060 * * \\
(0.030)\end{array}$ & $\begin{array}{c}0.037 \\
(0.031)\end{array}$ & $\begin{array}{l}0.048^{*} \\
(0.027)\end{array}$ & $\begin{array}{c}0.066 * * \\
(0.027)\end{array}$ \\
\hline Acq. $\times$ competition & & $\begin{array}{c}-0.189 * * * \\
(0.045)\end{array}$ & $\begin{array}{c}-0.188 * * * \\
(0.045)\end{array}$ & $\begin{array}{c}-0.001 * * \\
(0.001)\end{array}$ & $\begin{array}{c}-0.002 * * \\
(0.001)\end{array}$ & $\begin{array}{c}-0.171 * * * \\
(0.045)\end{array}$ & \\
\hline Acq. $\times$ low competition & & & & & & & $\begin{array}{c}0.004 * * * \\
(0.002)\end{array}$ \\
\hline Acq. $\times$ medium competition & & & & & & & $\begin{array}{c}0.001 \\
(0.001)\end{array}$ \\
\hline Acq. $\times$ high competition & & & & & & & $\begin{array}{c}-0.002 * \\
(0.001)\end{array}$ \\
\hline $\operatorname{Ln}($ size $)$ & & & $\begin{array}{c}-0.005 * * * \\
(0.002)\end{array}$ & $\begin{array}{c}-0.005 * * * \\
(0.002)\end{array}$ & $\begin{array}{c}-0.002 \\
(0.002)\end{array}$ & $\begin{array}{c}-0.005 * * * \\
(0.002)\end{array}$ & $\begin{array}{c}-0.005 * * * \\
(0.002)\end{array}$ \\
\hline Capital/L & & & $\begin{array}{c}0.001 \\
(0.001)\end{array}$ & $\begin{array}{c}0.003 * * * \\
(0.001)\end{array}$ & $\begin{array}{l}0.002 * \\
(0.001)\end{array}$ & $\begin{array}{c}0.001 \\
(0.001)\end{array}$ & $\begin{array}{c}0.001 \\
(0.001)\end{array}$ \\
\hline Share high skilled & & & $\begin{array}{l}-0.015 \\
(0.013)\end{array}$ & $\begin{array}{l}-0.013 \\
(0.014)\end{array}$ & $\begin{array}{l}-0.008 \\
(0.015)\end{array}$ & $\begin{array}{l}-0.016 \\
(0.013)\end{array}$ & $\begin{array}{l}-0.015 \\
(0.013)\end{array}$ \\
\hline $\begin{array}{l}\text { Share women } \\
\text { (industry) }\end{array}$ & & & & & & $\begin{array}{c}0.067 * * * \\
(0.011)\end{array}$ & \\
\hline Firm FE & yes & yes & yes & yes & yes & yes & yes \\
\hline Year FE & yes & yes & yes & yes & yes & yes & yes \\
\hline Observations & 128,848 & 128,848 & 128,848 & 110,952 & 87,409 & 128,848 & 128,848 \\
\hline No of Firms & 27,104 & 27,104 & 27,104 & 24,477 & 19,911 & 27,104 & 27,104 \\
\hline R-squared & 0.007 & 0.008 & 0.008 & 0.008 & 0.009 & 0.011 & 0.009 \\
\hline
\end{tabular}

The dependent variable is the share of women employed. Acquisition takes the value of one in the acquisition period and thereafter; zero before. Competition is the industry level of product market competition. $\mathrm{Ln}(\mathrm{size})$ is the log of the number of employees. Capital/L is the capital-labor ratio. Share high skilled is the share of employees with post-secondary education. Share women (industry) is the share of women employed at the two-digit industry level. Column (4) excludes all cross-border mergers and column (5) excludes all domestic mergers. All regressions include firm-level fixed effects and year fixed effects. Standard errors are adjusted for clustering at the firm level. ***, **, show significance at the 1,5 and 10 percent level, respectively. 
Table 5. The effect of takeovers and product market competition on the share of women employed. Firm-level estimates 1990-2002. Different trends for acquired firms and time varying explanatory variables.

\begin{tabular}{|c|c|c|c|c|c|c|}
\hline & $(1)$ & $(2)$ & (3) & $(4)$ & $(5)$ & $(6)$ \\
\hline & \multicolumn{6}{|c|}{ Only target firms } \\
\hline Acquisition & $\begin{array}{c}0.010 * * * \\
(0.002)\end{array}$ & & $\begin{array}{c}0.013 * * * \\
(0.003)\end{array}$ & & $\begin{array}{c}0.008 * * * \\
(0.002)\end{array}$ & \\
\hline Competition & $\begin{array}{c}0.076 * * * \\
(0.028)\end{array}$ & $\begin{array}{c}0.066 * * \\
(0.027)\end{array}$ & $\begin{array}{c}0.129 * * * \\
(0.049)\end{array}$ & $\begin{array}{c}0.100 * * \\
(0.046)\end{array}$ & $\begin{array}{c}0.055 * * \\
(0.028)\end{array}$ & $\begin{array}{l}0.047 * \\
(0.027)\end{array}$ \\
\hline Acq. $\times$ competition & $\begin{array}{c}-0.191 * * * \\
(0.044)\end{array}$ & & $\begin{array}{c}-0.239 * * * \\
(0.049)\end{array}$ & & $\begin{array}{c}-0.141 * * * \\
(0.044)\end{array}$ & \\
\hline Acq. $\times$ low competition & & $\begin{array}{c}0.005^{* * * *} \\
(0.002)\end{array}$ & & $\begin{array}{c}0.005^{* * * *} \\
(0.002)\end{array}$ & & $\begin{array}{c}0.003 * * \\
(0.002)\end{array}$ \\
\hline Acq. $\times$ medium competition & & $\begin{array}{c}0.001 \\
(0.001)\end{array}$ & & $\begin{array}{c}0.001 \\
(0.001)\end{array}$ & & $\begin{array}{c}0.001 \\
(0.001)\end{array}$ \\
\hline Acq. $\times$ high competition & & $\begin{array}{l}-0.002 * \\
(0.001)\end{array}$ & & $\begin{array}{c}-0.003 * * \\
(0.001)\end{array}$ & & $\begin{array}{c}-0.001 \\
(0.001)\end{array}$ \\
\hline Firm FE & yes & yes & yes & yes & yes & yes \\
\hline Year FE & yes & yes & yes & yes & yes & yes \\
\hline Target $\times$ trend & yes & yes & no & no & yes & yes \\
\hline Firm control & yes & yes & yes & yes & yes & yes \\
\hline Firm controls $\times$ Year FE & no & no & no & no & yes & yes \\
\hline Observations & 128,848 & 128,848 & 49,956 & 49,956 & 128,848 & 128,848 \\
\hline Number of firms & 27,104 & 27,104 & 8,609 & 8,609 & 27,104 & 27,104 \\
\hline R-squared & 0.01 & 0.01 & 0.01 & 0.01 & 0.01 & 0.01 \\
\hline
\end{tabular}

The dependent variable is the share of women employed. Acquisition takes the value of one in the acquisition period and thereafter; zero before. Competition is the industry level of product market competition. Firm controls are the same as in Table 4; the log of the number of employees, the capital-labor ratio and the share of high skilled. Targetxtrend is an interaction between firms that are ever takeover targets and a trend variable. Firm controls $\times$ Year FE means that firm controls are interacted with year fixed effects. All regressions include firm-level fixed effects and year fixed effects. Columns (3) and (4) only include firms that change ownership. Standard errors are adjusted for clustering at the firm level. ***,**, * show significance at the 1, 5 and 10 percent level, respectively. 
Table 6. The effect of takeovers and product market competition on the share of women employed. Firm-level estimates 1990-2002. Before and after analysis.

\begin{tabular}{|c|c|c|c|c|c|c|}
\hline & $(1)$ & $(2)$ & (3) & (4) & (5) & (6) \\
\hline & & & & & nly target fir & \\
\hline \multirow[t]{2}{*}{ Acquisition $\mathrm{t}-2$} & & -0.002 & -0.001 & & -0.001 & -0.001 \\
\hline & & $(0.001)$ & $(0.001)$ & & $(0.001)$ & $(0.001)$ \\
\hline \multirow[t]{2}{*}{ Acquisition t-1 } & & -0.001 & -0.001 & & -0.001 & -0.000 \\
\hline & & $(0.001)$ & $(0.001)$ & & $(0.002)$ & $(0.002)$ \\
\hline \multirow[t]{2}{*}{ Acquisition $\mathrm{t}=0$} & $0.010 * * *$ & $0.009 * * *$ & $0.009 * * *$ & $0.013 * * *$ & $0.012 * * *$ & $0.013 * * *$ \\
\hline & $(0.002)$ & $(0.003)$ & $(0.003)$ & $(0.003)$ & $(0.003)$ & $(0.003)$ \\
\hline \multirow[t]{2}{*}{ Acquisition $\mathrm{t}+1$} & $0.009 * * *$ & & $0.008 * * *$ & $0.012 * * *$ & & $0.011 * * *$ \\
\hline & $(0.003)$ & & $(0.003)$ & $(0.003)$ & & $(0.003)$ \\
\hline \multirow[t]{2}{*}{ Acquisition $\mathrm{t}+2$} & $0.010 * * *$ & & $0.009 * * *$ & $0.013 * * *$ & & $0.012 * * *$ \\
\hline & $(0.003)$ & & $(0.003)$ & $(0.003)$ & & $(0.003)$ \\
\hline \multirow[t]{2}{*}{ Acquisition $>t+2$} & $0.010 * * *$ & & $0.009 * * *$ & $0.014 * * *$ & & $0.013 * * *$ \\
\hline & $(0.003)$ & & $(0.003)$ & $(0.003)$ & & $(0.004)$ \\
\hline \multirow[t]{2}{*}{ Competition } & $0.074 * * *$ & $0.075 * * *$ & $0.074 * * *$ & $0.127 * * *$ & $0.128 * * *$ & $0.126 * * *$ \\
\hline & $(0.028)$ & $(0.028)$ & $(0.028)$ & $(0.049)$ & $(0.049)$ & $(0.049)$ \\
\hline \multirow[t]{2}{*}{ Acq. $\times$ competition } & $-0.184 * * *$ & $-0.186 * * *$ & $-0.183 * * *$ & $-0.236 * * *$ & $-0.236 * * *$ & $-0.234 * * *$ \\
\hline & $(0.045)$ & $(0.045)$ & $(0.045)$ & $(0.049)$ & $(0.049)$ & $(0.049)$ \\
\hline Firm FE & yes & yes & yes & yes & yes & yes \\
\hline Year FE & yes & yes & yes & yes & yes & yes \\
\hline Firm controls & yes & yes & yes & yes & yes & yes \\
\hline Observations & 128,848 & 128,848 & 128,848 & 49,956 & 49,956 & 49,956 \\
\hline Number of firms & 27,104 & 27,104 & 27,104 & 8,609 & 8,609 & 8,609 \\
\hline R-squared & 0.01 & 0.01 & 0.01 & 0.01 & 0.01 & 0.01 \\
\hline
\end{tabular}

The dependent variable is the share of women employed. Acquisition takes the value of one in the acquisition period and thereafter; zero before. Acquisition t-2 takes the value of one two years prior to the acquisition and zero otherwise. The other Acquisition $t+/$ - variables are defined accordingly. Firm controls are the same as in Table 4; the log of the number of employees, the capital-labor ratio and the share of high skilled. Columns (4)-(6) only include firms that change ownership. All regressions include firm-level fixed effects and year fixed effects. . Standard errors are adjusted for clustering at the firm level. ***, **, * show significance at the 1,5 and 10 percent level, respectively 
Table 7. Alternative explanations. Workforce composition and offshoring. Firm-level estimates 1990-2002.

\begin{tabular}{|c|c|c|c|c|c|c|c|}
\hline & (1) & (2) & (3) & (4) & (5) & $(6)$ & $(7)$ \\
\hline & $\operatorname{Ln}($ size $)$ & $\begin{array}{c}\text { Share } \\
\text { women 16- } \\
39 \text { years }\end{array}$ & $\begin{array}{c}\text { Share } \\
\text { women } 40+ \\
\text { years }\end{array}$ & \multicolumn{2}{|c|}{ Offshoring sar } & n employ & $\begin{array}{l}\text { Extreme } \\
\text { growth } \\
\text { firms } \\
\text { excluded }\end{array}$ \\
\hline Acquisition & $\begin{array}{l}0.031 * \\
(0.018)\end{array}$ & $\begin{array}{c}0.014 * * * \\
(0.004)\end{array}$ & $\begin{array}{c}0.015 * * * \\
(0.003)\end{array}$ & $\begin{array}{l}0.006 * \\
(0.003)\end{array}$ & $\begin{array}{l}0.006 * \\
(0.003)\end{array}$ & $\begin{array}{l}0.006 * \\
(0.003)\end{array}$ & $\begin{array}{c}0.010 * * * \\
(0.002)\end{array}$ \\
\hline Competition & $\begin{array}{c}0.129 \\
(0.192)\end{array}$ & $\begin{array}{c}0.130 * * * \\
(0.041)\end{array}$ & $\begin{array}{c}0.104 * * * \\
(0.039)\end{array}$ & $\begin{array}{c}0.016 \\
(0.048)\end{array}$ & $\begin{array}{c}0.016 \\
(0.048)\end{array}$ & $\begin{array}{c}0.014 \\
(0.048)\end{array}$ & $\begin{array}{c}0.081 * * * \\
(0.027)\end{array}$ \\
\hline $\begin{array}{l}\text { Acq.×competition } \\
\text { Offshoring } \\
\text { Offshoring } \times \text { comp. }\end{array}$ & $\begin{array}{l}-0.294 \\
(0.314)\end{array}$ & $\begin{array}{c}-0.297 * * * \\
(0.068)\end{array}$ & $\begin{array}{c}-0.258 * * * \\
(0.059)\end{array}$ & $\begin{array}{l}-0.112 * \\
(0.065)\end{array}$ & $\begin{array}{l}-0.112 * \\
(0.065) \\
-0.003 \\
(0.007)\end{array}$ & $\begin{array}{c}-0.107 * \\
(0.065) \\
-0.000 \\
(0.009) \\
-0.007 \\
(0.010)\end{array}$ & $\begin{array}{c}-0.185^{* * *} * \\
(0.045)\end{array}$ \\
\hline $\begin{array}{l}\text { Firm FE } \\
\text { Year FE } \\
\text { Firm controls }\end{array}$ & $\begin{array}{l}\text { yes } \\
\text { yes } \\
\text { yes }\end{array}$ & $\begin{array}{l}\text { yes } \\
\text { yes } \\
\text { yes }\end{array}$ & $\begin{array}{l}\text { yes } \\
\text { yes } \\
\text { yes }\end{array}$ & $\begin{array}{l}\text { yes } \\
\text { yes } \\
\text { yes }\end{array}$ & $\begin{array}{l}\text { yes } \\
\text { yes } \\
\text { yes }\end{array}$ & $\begin{array}{l}\text { yes } \\
\text { yes } \\
\text { yes }\end{array}$ & $\begin{array}{l}\text { yes } \\
\text { yes } \\
\text { yes }\end{array}$ \\
\hline $\begin{array}{l}\text { Observations } \\
\text { Number of firms }\end{array}$ & $\begin{array}{c}128,848 \\
27,104 \\
\end{array}$ & $\begin{array}{c}128,510 \\
27,007\end{array}$ & $\begin{array}{c}127,675 \\
26,703\end{array}$ & $\begin{array}{l}77,766 \\
21,449\end{array}$ & $\begin{array}{l}77,766 \\
21,449\end{array}$ & $\begin{array}{l}77,766 \\
21,449\end{array}$ & $\begin{array}{c}127,830 \\
26,937\end{array}$ \\
\hline R-squared & 0.08 & 0.01 & 0.00 & 0.01 & 0.01 & 0.01 & 0.01 \\
\hline $\begin{array}{l}\text { The dependent vari } \\
\text { ratio and the share } \\
\text { women employed, } \\
\text { controls are the sar } \\
\text { high skilled. Colum } \\
\text { excluded which inc } \\
\text { adjusted for cluster }\end{array}$ & $\begin{array}{l}\text { le in colur } \\
\text { f high skil } \\
\text { spectively } \\
\text { as in Tab } \\
\text { s (4)-(6) or } \\
\text { ase more t } \\
g \text { at the fir }\end{array}$ & $\begin{array}{l}\text { (1) is the lo } \\
\text { In columns } \\
n \text { columns ( } \\
4 \text {; the log } \\
y \text { include fir } \\
\text { an } 80 \text { percen } \\
\text { level. } * * * \text {, * }\end{array}$ & $\begin{array}{l}\text { of the numbe } \\
\text { and ( } 3 \text { ) the } \\
(7) \text {, the depe } \\
\text { the number } \\
\text { for which w } \\
\text { n size during } \\
* \text { show signi }\end{array}$ & $\begin{array}{l}\text { f employ } \\
\text { pendent } \\
\text { nt varial } \\
\text { mployee } \\
\text { ave data } \\
\text { year of } \\
\text { ance at } t\end{array}$ & $\begin{array}{l}\text { and firm } \\
\text { ables are } \\
\text { the shar } \\
\text { e capital } \\
\text { ffshoring } \\
\text { wnership } \\
5 \text { and } 10\end{array}$ & $\begin{array}{l}\text { rols are } t \\
\text { share of } \\
\text { women } \\
\text { or ratio a } \\
\text { in colur } \\
\text { inge. Stal } \\
\text { cent leve }\end{array}$ & $\begin{array}{l}\text { apital-labo } \\
\text { ing and old } \\
\text { loyed. Firn } \\
\text { the share o } \\
\text { 7) firms are } \\
\text { d errors are } \\
\text { spectively. }\end{array}$ \\
\hline
\end{tabular}


Table 8. The effect on various employee sub-groups

\begin{tabular}{|c|c|c|c|c|c|}
\hline & (1) & $(2)$ & (3) & (4) & (5) \\
\hline & $\begin{array}{c}\text { Low } \\
\text { Education }\end{array}$ & Medium Education & High Education & Managers & CEOs \\
\hline Acquisition & $\begin{array}{c}-0.006 \\
(0.010)\end{array}$ & $\begin{array}{c}0.022 * * * \\
(0.008)\end{array}$ & $\begin{array}{c}0.001 \\
(0.013)\end{array}$ & $\begin{array}{c}0.004 \\
(0.013)\end{array}$ & $\begin{array}{c}-0.002 \\
(0.027)\end{array}$ \\
\hline Competition & $\begin{array}{c}0.039 \\
(0.096)\end{array}$ & $\begin{array}{c}0.058 \\
(0.091)\end{array}$ & $\begin{array}{c}-0.043 \\
(0.168)\end{array}$ & $\begin{array}{l}-0.058 \\
(0.212)\end{array}$ & $\begin{array}{c}-0.038 \\
(0.423)\end{array}$ \\
\hline Acq. $\times$ competition & $\begin{array}{c}0.029 \\
(0.151)\end{array}$ & $\begin{array}{c}-0.347 * * * \\
(0.125)\end{array}$ & $\begin{array}{l}-0.209 \\
(0.221)\end{array}$ & $\begin{array}{l}-0.131 \\
(0.250)\end{array}$ & $\begin{array}{c}0.101 \\
(0.449)\end{array}$ \\
\hline Firm FE & yes & yes & yes & yes & yes \\
\hline Year FE & yes & yes & yes & yes & yes \\
\hline Firm controls & yes & yes & yes & yes & yes \\
\hline Observations & 35,355 & 40,283 & 25,053 & 15,872 & 8,050 \\
\hline Number of firms & 11,004 & 12,433 & 7,677 & 5,355 & 3,450 \\
\hline R-squared & 0.01 & 0.02 & 0.02 & 0.01 & 0.00 \\
\hline
\end{tabular}

The dependent variable is the share of women among employees with low education (column (1)), medium education (column (2)) and high education (column (3)). In column (4) the dependent variable is the share of female managers and column (5) female CEOs. Acquisition takes the value of one in the acquisition period and thereafter; zero before. Competition is the industry level of product market competition. Firm controls are the same as in Table 4; the log of the number of employees, the capital-labor ratio and the share of high skilled. All regressions include firm-level fixed effects and year fixed effects. Standard errors are adjusted for clustering at the firm level. $* * *, * *, *$ show significance at the 1,5 and 10 percent level, respectively. 
Table 9. The effect of takeovers and product market competition on women's relative wages. Individual-level estimates 1990-2002.

\begin{tabular}{|c|c|c|c|c|c|c|}
\hline & (1) & (2) & (3) & (4) & (5) & (6) \\
\hline Acquisition & $\begin{array}{c}-0.005 \\
(0.004)\end{array}$ & $\begin{array}{c}-0.006 \\
(0.009)\end{array}$ & $\begin{array}{c}-0.006 \\
(0.004)\end{array}$ & & $\begin{array}{c}-0.005 \\
(0.004)\end{array}$ & $\begin{array}{c}-0.005 \\
(0.003)\end{array}$ \\
\hline Wom. $\times$ Acq. & $\begin{array}{c}0.008 * * \\
(0.003)\end{array}$ & $\begin{array}{c}0.008 \\
(0.006)\end{array}$ & $\begin{array}{c}0.006 * * \\
(0.003)\end{array}$ & & $\begin{array}{c}0.006 * * \\
(0.003)\end{array}$ & $\begin{array}{l}0.006^{*} \\
(0.004)\end{array}$ \\
\hline Competition & $\begin{array}{c}-0.292 * * * \\
(0.102)\end{array}$ & $\begin{array}{c}-0.295 * * * \\
(0.106)\end{array}$ & & $\begin{array}{c}-0.284 * * * \\
(0.105)\end{array}$ & $\begin{array}{c}-0.275 * * * \\
(0.105)\end{array}$ & $\begin{array}{c}-0.275 \\
(0.172)\end{array}$ \\
\hline Wom.×Comp. & $\begin{array}{c}0.110 \\
(0.076)\end{array}$ & $\begin{array}{c}0.113 \\
(0.084)\end{array}$ & & $\begin{array}{c}0.122 \\
(0.077)\end{array}$ & $\begin{array}{c}0.107 \\
(0.077)\end{array}$ & $\begin{array}{c}0.107 \\
(0.118)\end{array}$ \\
\hline Wom. $\times$ Comp. $\times$ Acq. & & $\begin{array}{l}-0.012 \\
(0.092)\end{array}$ & & & & \\
\hline Comp. $\times$ Acq. & & $\begin{array}{c}0.011 \\
(0.147)\end{array}$ & & & & \\
\hline Wom. $\times$ Profits $/ \mathrm{L}$ & & & $\begin{array}{l}-0.000 \\
(0.001)\end{array}$ & $\begin{array}{c}0.003 \\
(0.005)\end{array}$ & $\begin{array}{c}-0.006 \\
(0.005)\end{array}$ & $\begin{array}{c}-0.006 \\
(0.007)\end{array}$ \\
\hline Profits/L & & & $\begin{array}{c}0.001 \\
(0.003)\end{array}$ & $\begin{array}{c}0.010 \\
(0.010)\end{array}$ & $\begin{array}{c}0.015^{* *} \\
(0.007)\end{array}$ & $\begin{array}{l}0.015^{*} \\
(0.009)\end{array}$ \\
\hline Acq.×Profits/L & & & $\begin{array}{l}-0.003 \\
(0.007)\end{array}$ & & $\begin{array}{l}-0.005 \\
(0.007)\end{array}$ & $\begin{array}{l}-0.005 \\
(0.008)\end{array}$ \\
\hline Wom $\times$ Acq.$\times$ Profits $/ L$ & & & $\begin{array}{c}0.007 * \\
(0.003)\end{array}$ & & $\begin{array}{c}0.007 * * \\
(0.003)\end{array}$ & $\begin{array}{l}0.007 * \\
(0.004)\end{array}$ \\
\hline Comp. $\times$ Profits $/ \mathrm{L}$ & & & & $\begin{array}{c}-0.179 \\
(0.142)\end{array}$ & $\begin{array}{c}-0.223 * * \\
(0.107)\end{array}$ & $\begin{array}{c}-0.223^{*} \\
(0.128)\end{array}$ \\
\hline Wom. $\times$ Comp.$\times$ Profits $/ \mathrm{L}$ & & & & $\begin{array}{c}0.012 \\
(0.080)\end{array}$ & $\begin{array}{c}0.089 \\
(0.072)\end{array}$ & $\begin{array}{c}0.089 \\
(0.103)\end{array}$ \\
\hline Spell FE & yes & yes & yes & yes & yes & yes \\
\hline Year FE & yes & yes & yes & yes & yes & yes \\
\hline Year FE**wom & yes & yes & yes & yes & yes & yes \\
\hline Control variables & yes & yes & yes & yes & yes & yes \\
\hline Control variables*wom & yes & yes & yes & yes & yes & yes \\
\hline Observations & $9,989,595$ & $9,989,595$ & $9,989,595$ & $9,989,595$ & $9,989,595$ & $9,989,595$ \\
\hline Number of spells & $3,327,793$ & $3,327,793$ & $3,327,793$ & $3,327,793$ & $3,327,793$ & $3,327,793$ \\
\hline R-squared & 0.45 & 0.45 & 0.45 & 0.45 & 0.45 & 0.45 \\
\hline
\end{tabular}

The dependent variable is log wages. Acquisition takes the value of one in the acquisition period and thereafter; zero before. Competition is the industry level of product market competition. Profits/L is the profits per employee. Individual control is the square of work experience. Individual level control is potential experience squared. Firm controls are the log of the number of employees, the capital-labor ratio and the share of employees with postsecondary education. All regressions include spell (individual $\times$ firm) and year fixed effects. In all columns, standard errors are adjusted for clustering at the firm level, except column (6) where they are clustered at the 2-digit industry level. $* * *, * *, *$ show significance at the 1,5 and 10 percent level, respectively. 